\title{
The Blue Ocean Strategy in the Context of Management and Development of the Number of Jobs
}

\author{
Marcela GALOVSKÁ \\ University of Economics in Bratislava, Bratislava, Slovakia \\ galovska@azet.sk
}

\begin{abstract}
Currently, the main goal of a company is to be more successful than competition and to gain a higher profit. One of the options for companies is the use of the Blue Ocean Strategy, i.e. to create your own market space. The aim of this contribution is to highlight the Blue Ocean Strategy in the context of management and development of the number of jobs.

In the second part of the contribution we will focus on the relationship and the impact of the Blue Ocean Strategy on managerial functions. We will deal more closely with the planning and human resources functions that are affected by the strategy. For the planning function we will point out mainly to a plan, a component of marketing. In human resources we will draw attention to creative thinking when creating new markets. In the following part we will break down the confidence of the economic assortment indicators and the development of the number of jobs within the Slovak Republic

In the contribution through secondary statistics and regression analysis and Pearson correlation, I will evaluate the impact of the business environment, i.e., External and internal conditions to develop the number of vacancies. I contribute to the changes that have occurred in the managerial positions and their impact on the business environment on the trend of production automation and global job cuts.
\end{abstract}

Keywords: Blue Ocean Strategy, Number of Jobs, Management.

\section{The Blue Ocean Strategy in the context of business management}

The Blue Ocean Strategy was defined by W.Chan Kim and Renée Mauborgne, who characterised the differences between the blue and the red ocean. [12] The existing industries and certain boundaries of competitors are specific for the red ocean. In presence, the competition in a market space is oversaturated. The Blue Ocean Strategy is defined by creating new, i.e. non-existing industries; new market space and many opportunities for a business growth are created in the blue ocean. 
Table 1. The differences between the Blue and the Red Ocean [9]

\begin{tabular}{|c|c|}
\hline Red Ocean & Blue Ocean \\
\hline Competition in existing market space & Creation of new market space \\
\hline $\begin{array}{l}\text { Competitive environment - beating the } \\
\text { competition }\end{array}$ & Irrelevance of competition \\
\hline Exploiting existing demand & Creating and capturing new demand \\
\hline Compliance: value / cost & Non-compliance: value / cost \\
\hline $\begin{array}{l}\text { Align the whole system: employers' } \\
\text { activities, strategic choice of } \\
\text { differentiation or low cost. }\end{array}$ & $\begin{array}{l}\text { Align the whole system: the consistency of } \\
\text { employers' activities in pursuit of } \\
\text { differentiation or low cost. }\end{array}$ \\
\hline
\end{tabular}

The term strategy has its origin in the military. In the 20th century complicated external influences and dynamic changes occurred, penetrating into the company and relating to the term strategy. W.Chan Kim and Renée Mauborgne defined the Blue Ocean Strategy, analysed their research in 30 various industries based on 150 strategic goals in the period from 1880 to 2000. [12]

According to [7] the test a new generation of strategic management theories to discover the most appropriate qualitative factors Multiple regression analysis has shown that the set of all researched independent and moderating variables is strongly correlated with a startup success and can predict e-business successful performance in more than $80 \%$ of the cases. [1] proposes that blue oceans can be created via radical innovation, disruptive innovation, frugal innovation, and purely differentiation strategy and focused differentiation strategy rather than only value innovation. We, thus extend the boundaries of sources of blue oceans.

Research into $[5 ; 17 ; 3]$ new dimensions of performance and value have been introduced. The lesson learned from this survey is that certain strategies based on the fulfillment of established or overlooked customer needs provide greater market appraisal.

[13] It presents paths to a formulating strategy focused on innovation and approaches to value. It also introduces the main barriers to an enterprise's innovative activities and their types.

Businesses apply strategies in their life cycle at the time of stagnation or bankruptcy. Following the global economic crisis the companies are making greater use of the Blue Ocean Strategy. The use of the strategy influences managerial functions to a large extent. Basic managerial functions include planning, organising, human resources, management and control.

Planning is a basic managerial function; it determines the future goals of the company and its paths. Proposals, solutions, systems of plans are the result of the planning activity. Planning is a formal approach to setting up the company's goals. Planning is one of the managerial functions characterised by its importance. None of the theoreticians in the management field in defining managerial functions missed the planning function. In the sense of Waterman R. H. the best companies consider the planning process more important than the plans themselves for generating new 
information, problems, critical parts etc. [18] Unless sufficient space is created for strategic planning, new thoughts and ideas in the planning process can be reduced.

Planning is the most important managerial function, for each decade of a period the function has different effective methods used in strategic management. The Blue Ocean Strategy is one of the methods of higher significance after the year 2008, i.e. the period of the commencement of the economic crisis.

Based on the content-subject component of a plan of a company the plans can be broken down by the following functional areas:[4]

- marketing;

- production and material needs;

- investment projects;

- human resources;

- financial plans.

According to [22] We build on contingency theory to examine how growing turbulence may have impacted three aspects of strategic planner jobs: temporal range, processes, and organizational location. Overall, the study suggests that choosing the right ownership form can have important strategic consequences. This authors [ 8] examines the extent to which ownership form (i.e., public or private ownership) and ownership structure (including diffused ownership and block holding) affect firm performance. The results of an analysis of 30,525 European Union (EU) firms indicate that form of ownership is an important explanatory factor in the difference in performance among firms.

The second managerial function we will deal with is human resources. Human resources are currently an important source of a company, it is necessary to manage them and create an effective environment for them to be creative.

Human resources management is strategic and holistic approach to management with the most valuable assets of a company, people, who individually and collectively contribute to achieving the organisational goals [2].

The pivotal role of human capital in this relationship :[11] knowledge-based HRM practices impact structural and relational capital partially through human capital, and human capital affects innovation performance by enhancing structural and relational capital. Based on the field of personnel measures and staff-welfare measures the authors [21] identified two polarized ideal types of personnel strategies: a requirements-centered strategy, which is strongly future-oriented and subordinates all other concerns to the implementation of the transformation vision and a caring strategy, which focuses more on the here and now and emphasizes also the fulfillment of staff needs. On the other hands [10] the relationship between board effectiveness and innovation varied by the type of innovation.

For the Blue Ocean Strategy human resources are very fundamental, after 2010 a new paradigm has occurred. A firm is a live organism and is built on people and knowledge. Management occurs based on opportunities, a market of thoughts and ideas and managers of innovations and knowledge prevail.

The Blue Ocean Strategy is built on creating new market space and value innovation, which is influenced by a value for a customer and by costs. The planning 
and human resources functions are affected by the Blue Ocean Strategy mainly for marketing, the content-subject component of a plan and creation of an effective environment for human resources to have creative ideas.

\section{Development of the number of jobs within the Slovak Republic}

The development of the number of jobs in the Slovak Republic has been decreasing since the global economic crisis; another factor is the introduction of industry 4.0. At present, some countries are trying to introduce a certain permanent income for their citizens in their projects. Work will have a status of volunteer, i.e. The individual decides whether to work. Salary or wages for work will be for permanent income as extra money. The countries have decided to implement the project because of two trends, namely job cuts (industry 4.0) and a growing number of social spending for countries. The following chart shows the development of the number of vacancies within the Slovak Republic.

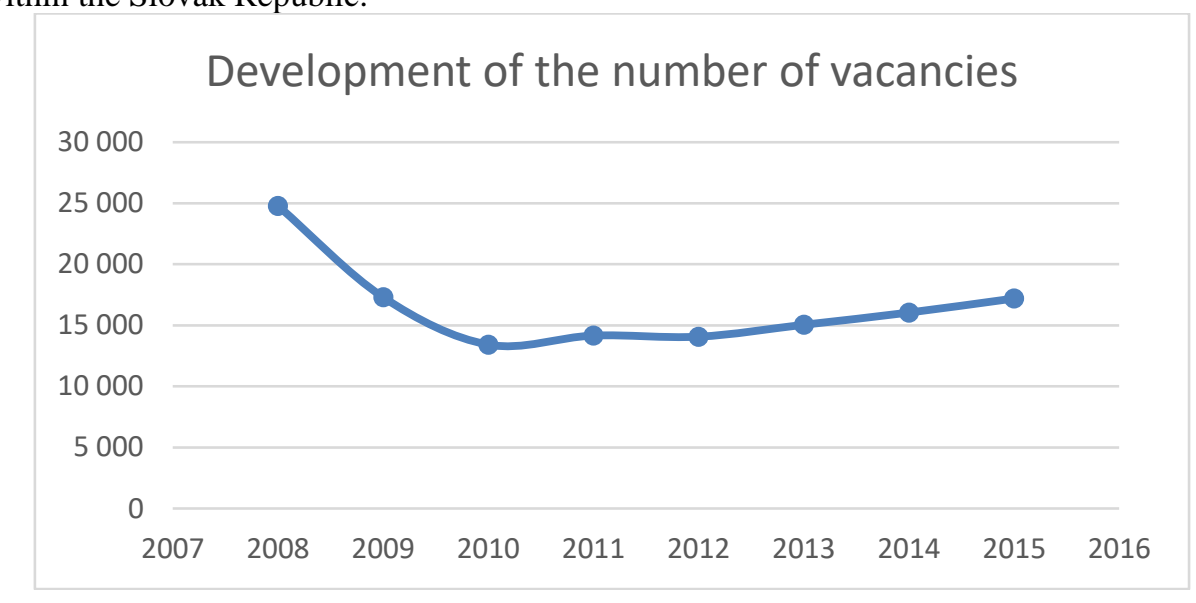

Fig. 1. Development of the number of vacancies [19]

Since 2008, the number of vacancies declined. Graph shows mild stagnation starting from 2010 and from 2012 with a slight increase.

On the other hand, as the number of jobs decreases, it is also important to assess the development of the number of businesses in terms of trust. The following graph, which shows the development of trust of the economic assortment indicators, i.e. industry, construction, retail, consumers, has been processed through macroeconomic statistics. 


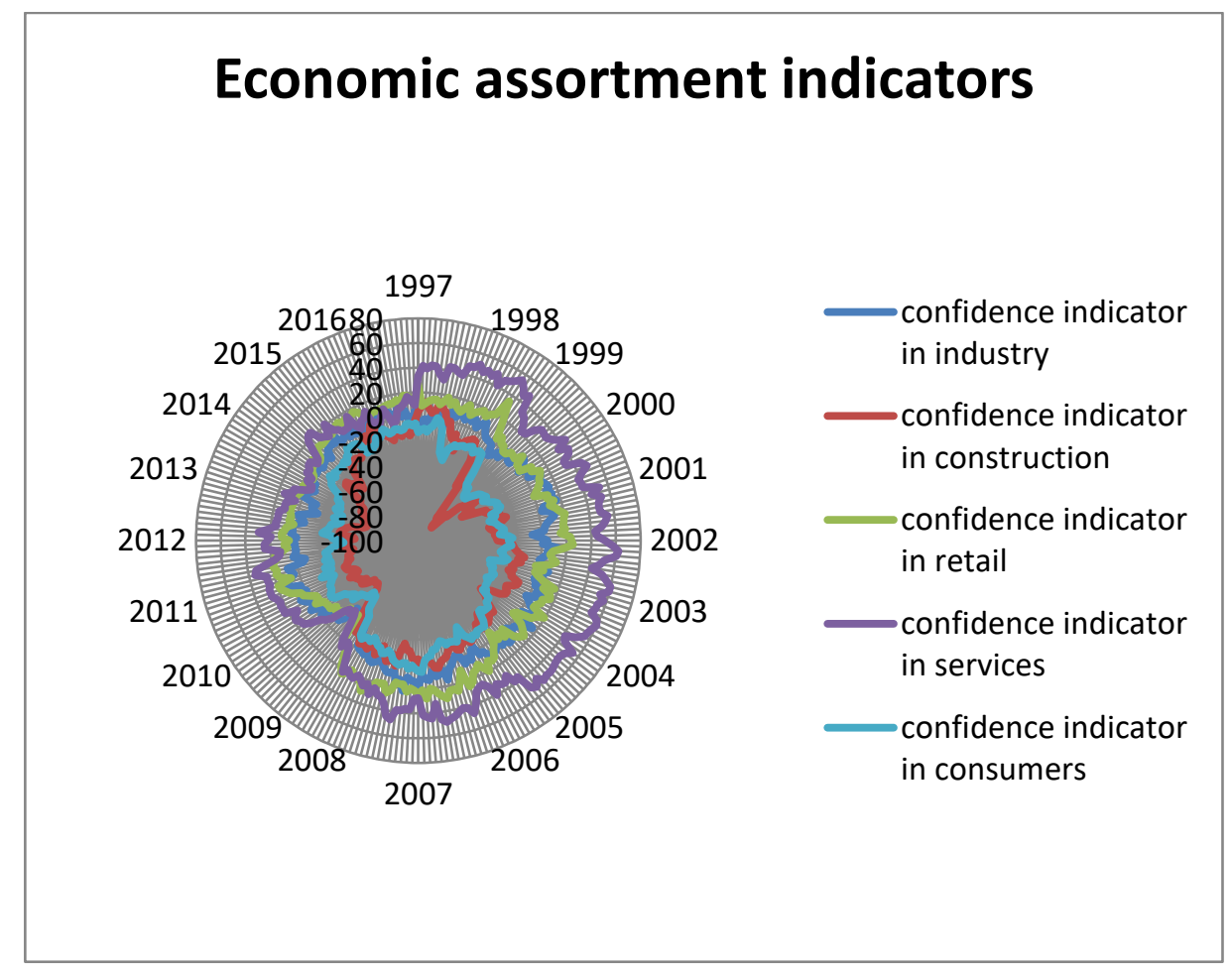

Fig. 2. Economic assortment indicators [19]

The (Fig.2) shows the development period of the economic assortment from 1997 to 2016 in monthly intervals. From 2008 the development of trust in all assortments has decreased, around 2009 and 2010 there was a significant decline, in 2011 and 2012 there was a growing trend and subsequently, the expression of trust has stagnated or fallen. The development in 2016 in the given assortments is almost the same. The global economic crisis caused a drop in employees, an increase in the disappearances of firms, but it also expressed itself in terms of trust in the given economic segments. It is interesting to watch the changes in terms of the graph due to the differences. The development since 1997 has had more distinct differences between the economic assortments; the global economic crisis caused a decline. After its outbreak and implementation of new solutions the expression of trust in the economic assortments was different, but after 2013 the trust has started to express identical in terms of values in the given assortments, or there has been a slight difference. Based on the given development of the graph it is important to note that evaluation and identification of changes caused by the global economic crisis is effective to be investigated after some time. 


\section{Discussion}

Businesses are also effectively investigated from the point of view of management. Through regression statistics, I will compare the external and internal conditions that the Business Alliance of Slovakia [6] has identified in the inter-quarter development as important for the impact of the business environment.

In terms of external conditions, it has determined: state economic policy, bureaucracy, level of corruption in offices, price stability, access to financial resources, financial discipline of business partners and others. In the internal conditions, she defined: fulfilment of vision and business intentions, productivity, performance, human resources management, liquidity, employment, environmental relations, information openness and others.

Table 2. Regression statistics of external and internal conditions in the business environment

\begin{tabular}{|c|c|c|c|c|c|c|c|c|}
\hline \multicolumn{9}{|l|}{ RESULT } \\
\hline \multicolumn{9}{|c|}{ Regression statistics } \\
\hline & \multicolumn{8}{|l|}{0.9108} \\
\hline $\mathrm{R} 2$ & \multicolumn{8}{|l|}{99635} \\
\hline Value of & \multicolumn{8}{|l|}{0.8297} \\
\hline reliability $\mathrm{R}$ & \multicolumn{8}{|l|}{38146} \\
\hline Setting & \multicolumn{8}{|l|}{0.8013} \\
\hline reliability $\mathrm{R}$ & \multicolumn{8}{|l|}{6117} \\
\hline Mean value & \multicolumn{8}{|l|}{8.2049} \\
\hline error & \multicolumn{8}{|l|}{53733} \\
\hline Observation & \multicolumn{8}{|l|}{8} \\
\hline \multicolumn{9}{|l|}{ ANOVA } \\
\hline & \multirow[t]{2}{*}{ df } & SS & MS & $\mathrm{F}$ & $\begin{array}{l}\text { Significa } \\
\text { nce of F }\end{array}$ & & & \\
\hline & & 1968.462 & 1968 & 29.239 & 0.001652 & & & \\
\hline \multirow[t]{2}{*}{ Regression } & \multirow[t]{2}{*}{1} & 843 & .463 & 8371 & 324 & & & \\
\hline & & 403.9275 & 67.3 & & & & & \\
\hline \multirow[t]{2}{*}{ Residues } & \multirow[t]{2}{*}{6} & 945 & 2127 & & & & & \\
\hline & & 2372.390 & & & & & & \\
\hline \multirow[t]{4}{*}{ Total } & \multirow[t]{2}{*}{7} & 438 & & & & & & \\
\hline & & $\begin{array}{l}\text { Mean } \\
\text { value }\end{array}$ & & Value & Lower & Upper & Lower & Upper \\
\hline & $\begin{array}{l}\text { Coeffic } \\
\text { ients }\end{array}$ & error & t Stat & $\mathrm{P}$ & $95 \%$ & $95 \%$ & $95.0 \%$ & $95.0 \%$ \\
\hline & 399.48 & 59.91539 & 6.66 & 0.0005 & 252.8804 & 546.09 & 252.88 & 546.09 \\
\hline \multirow[t]{3}{*}{ Limit } & 81644 & 028 & 7538 & 5075 & 862 & 58427 & 0486 & 5843 \\
\hline & \multicolumn{2}{|l|}{-} & - & & - & - & - & - \\
\hline & 1.2320 & 0.227854 & 5.40 & 0.0016 & 1.789637 & 0.6745 & 1.7896 & 0.6745 \\
\hline The file $\mathrm{X} 1$ & 97872 & 565 & 739 & 5232 & 905 & 5784 & 379 & 5784 \\
\hline
\end{tabular}


On the basis of regression statistics of internal and external data on the impact of the business environment, the confidence value is $82.976 \%$. The model is statistically appropriate based on significance $\mathrm{F}$ whose value is less than $\alpha=0.05$ i.e. the statistical units represent the scale value $\mathrm{n}=8$.

The regression analysis is shown in the following graph, which expresses the statistical dependence between external and internal conditions.

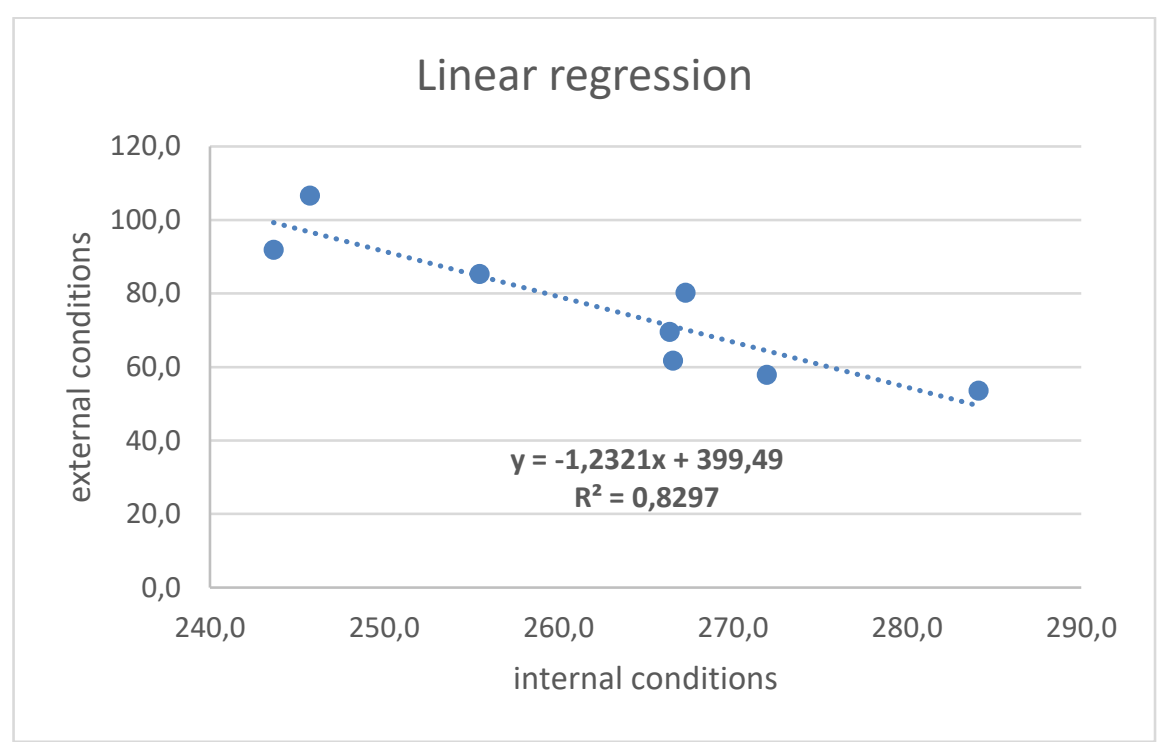

Fig. 3. Regression analysis - external and internal conditions [6]

The graph shows the relationship of regression analysis:

$$
y_{i}=f\left(x_{i}\right)+\epsilon_{i}
$$

Legend: $y_{i}, x_{i}$ - character values,

$\epsilon_{\mathrm{i}}$ - residual component,

f- regression function.

The regression analysis of the dependence of the inner and outer conditions has a linear negative shape.

Through Pearson's correlation I will examine the linear relationship between job vacancies and external conditions affecting the development of the business environment. 
Table 3. Calculation of Pearson Correlation-vacancies and external conditions

Double-breasted pair $t$-test at the mean value

\begin{tabular}{lll}
\hline & vacancies & external conditions \\
\hline Mean value & 16507.625 & 75.8824042 \\
dispersion & 13303321.13 & 338.9129197 \\
Observation & 8 & 8 \\
Pears. correlation & 0.548748518 & \\
Hyp. Difference of mean value & 0 & \\
difference & 7 & \\
$\mathrm{t}$ Stat & 12.77759854 & \\
$\mathrm{P}(\mathrm{T}<=\mathrm{t})(1)$ & $2.08379 \mathrm{E}-06$ & \\
$\mathrm{t}$ crit $(1)$ & 1.894578604 & \\
$\mathrm{P}(\mathrm{T}<=\mathrm{t})(2)$ & $4.16758 \mathrm{E}-06$ & \\
$\mathrm{t}$ crit $(2)$ & 2.364624251 & \\
\hline
\end{tabular}

Source: [6;19]

Pearson Correlation Calculation:

$$
r=\frac{\sum x_{i y_{i}}-\frac{\sum x_{i \sum y_{i}}}{n}}{\left.\left.\sqrt{\left(\sum x_{i}^{2}\right.}-\frac{\left(\sum x_{i}\right)^{2}}{n}\right) \sqrt{\left(\sum y_{i}^{2}\right.}-\frac{\left(\sum y_{i}\right)^{2}}{n}\right)}
$$

The evaluation of Pearson correlation is as follows:

$0<|\mathrm{r}| \leq 0.3$ - weak dependence,

$0.3<|\mathrm{r}| \leq 0.8$ - mild to moderate dependence,

$0.8<|\mathrm{r}| \leq 1$ - strong dependence.

The Pearson correlation value is 0.548748518 , representing a mean dependency. 


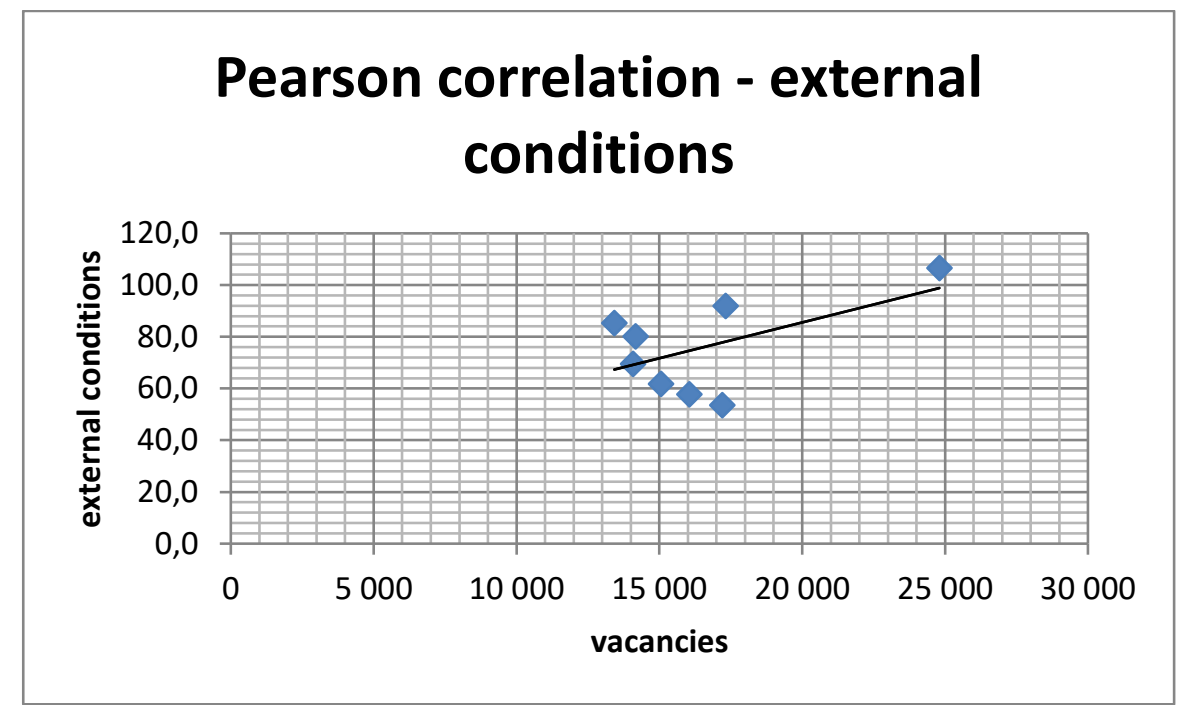

Fig. 4. Pearson correlation - external conditions

The graph shows a Pearson correlation that has a positive linear dependence.

On the other hand, we will examine the dependence between the number of workplaces and the internal conditions that affect the business environment.

Table 4. Calculation of Pearson correlation-vacancies and internal conditions

Double-breasted pair t-test at the mean value

\begin{tabular}{lll}
\hline & vacancies & $\begin{array}{l}\text { internal } \\
\text { conditions }\end{array}$ \\
\hline Mean value & 16507.625 & 262.6461482 \\
dispersion & 13303321.13 & 185.2417038 \\
Observation & 8 & 8 \\
Pears. correlation & -0.427610287 & \\
Hyp. Difference of mean value & 0 & \\
difference & 7 & \\
$\mathrm{t}$ Stat & 12.57735196 & \\
$\mathrm{P}(\mathrm{T}<=\mathrm{t})(1)$ & $2.31788 \mathrm{E}-06$ & \\
$\mathrm{t}$ crit $(1)$ & 1.894578604 & \\
$\mathrm{P}(\mathrm{T}<=\mathrm{t})(2)$ & $4.63576 \mathrm{E}-06$ & \\
$\mathrm{t}$ crit $(2)$ & 2.364624251 & \\
\hline
\end{tabular}


The Pearson correlation value is -0.427610287 , which represents the mean dependence.

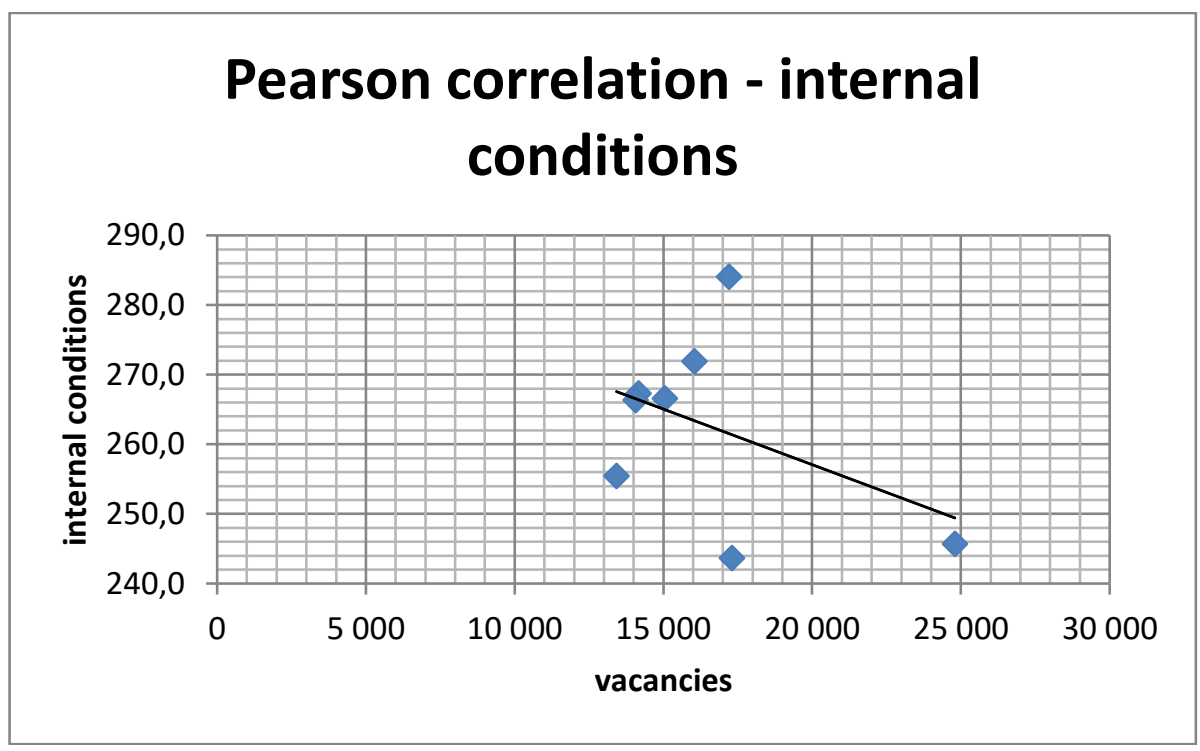

Fig.5. Pearson correlation - internal conditions

The development of the Pearson correlation for internal conditions has a negative linear evolution. On the other hand, there is a higher range of values than the Pearson correlation of external conditions.

\section{Summary}

At the moment with the onset of automated production, the number of jobs in a global character will have a decreasing trend. In my contribution I drew attention to the use of the Blue Ocean strategy in the context of business management. Subsequently, through statistical methods, namely regression analysis and Pearson correlation, I have evaluated from external statistical data the external and internal conditions that affect the working environment and the number of jobs in the Slovak Republic.

At present, businesses should focus on:

- business environment assessment,

- external conditions that have a greater impact on the number of vacancies,

- internal conditions that are characterized by lower efficiency,

- changes that occur in management methods and techniques in the context of enterprise development,

- the number of vacancies (industry 4.0),

- the Blue Ocean Strategy within Managerial planning and Human Resources 
Business confidence indicators have also been taken into account in the economic assortment. In the number of vacancies for external conditions, the comparison was evaluated as the mean dependence of positive linear development. From this result, I conclude that external conditions are to a large extent significant for the impact of the business environment whose development from the global economic crisis is inefficient. Although the external factor has a considerable impact on business management and its changes, which occur with turbulent times and extremes, The crises that have been and will be under development. In my contribution, I concentrated on the blue ocean strategy from a management point of view, namely the impact on planning and human resources.

\section{References}

1. Agnihotri, A.: Extending boundaries of Blue Ocean Strategy. Journal of Strategic Marketing 24(6), 519-528 (2016).

2. Armstrong, M.: Ǩízení lidských zdrojů. Nejnovější trendy a postupy. Grada Publishing, Praha (2007).

3. Bhargava, A.: Blue ocean strategy: A necessity prescription for companies. Maximizing Business Performance and Efficiency Through Intelligent Systems. University of Kota, India (2017).

4. Bilton, Ch.: Management and Creativity: From Creative Industries to Creative Management. John Wiley and Sons Ltd., New York City (2007).

5. Borgianni, Y., Cascini, G., Rotini, F.: Investigating the patterns of value-oriented innovations in blue ocean strategy. International Journal of Innovation Science 4(3), 123142 (2012).

6. Business Alliance of Slovakia: http://alianciapas.sk/, last accessed 2017/10/10.

7. Čirjevskis, A.: Exploration of qualitative success factors of innovative e-business startups: Blue ocean strategy versus dynamic capabilities. International Journal of Business Excellence 13(4), 459-478 (2017).

8. Fitza, M., Tihanyi, L.: How Much Does Ownership Form Matter? Strategic Management Journal 38(13), 2726-2743 (2017).

9. Harvard business review 2004. Blue ocean strategy, https://hbr.org/2004/10/blue-oceanstrategy, last accessed 2017/10/10.

10. Jaskyte, K.: 2017. Board Effectiveness and Innovation in Nonprofit Organizations. Human Service Organizations Management, Leadership and Governance 41(5), 453-463 (2017).

11. Kianto, A., Sáenz, J., Aramburu, N.: Knowledge-based human resource management practices, intellectual capital and innovation. Journal of Business Research 81, 11-20 (2017).

12. Kim, W. CH., Mauborgne, R.: Blue ocean strategy: How to Create Uncontested Market Space and Make the Competition Irrelevant. Harvard Business School Press, Boston (2005).

13. Krause, J.: Factors hampering innovation activities - Case study from the Czech Republic. Journal of Technology Management and Innovation 11(4), 75-79 ( 2016).

14. Majtán, M.: Manažment. Sprint dva. Bratislava (2009).

15. Mazouch, P., Fischer, J.: Lidský kapitál - měření, souvislosti, prognózy. C.H.Beck, Bratislava: (2011).

16. Pacáková, V.: Štatistika pre ekonómov. Iura edition, Bratislava (2003). 
17. Pistol, L., Tonis, R.: Model for innovation through information network sharing. Journal of Applied Economic Sciences 10(4), 509-513 (2015).

18. Sedlák, M.: Manažment. IuraEdition. Bratislava (2009).

19. Statistical Office of the Slovak Republic: http://datacube.statistics.sk/, last accessed 2017/10/12.

20. Šoltés, E. et al.: Štatistické metódy pre ekonómov: zbierka príkladov. Wolters Kluwer, Bratislava (2015).

21. Tollarová, B., Furmaníková, L.: Personnel Strategies in the Deinstitutionalization Process: How Do the Managers Work With Employees? Human Service Organizations Management, Leadership and Governance 41(5),. 532-559 (2017).

22. Whittingron, R., Yakis-Douglas, B., Ahn, K., Cailluet, L.: Strategic Planners in More Turbulent Times: The Changing Job Characteristics of Strategy Professionals, 19602003. Long range planning 50(1), 108-119 (2017). 